\title{
Re-induction of desiccation tolerance after germination of Cedrela fissilis Vell. seeds
}

\author{
TATHIANA E. MASETTO ${ }^{1}$, JOSE M. FARIA ${ }^{2}$ and ANA C.R. FRAIZ ${ }^{3}$ \\ ${ }^{1}$ Universidade Federal da Grande Dourados/UFGD, Faculdade de Ciências Agrárias, \\ Rodovia Dourados-Itahum, Km 12, 79804-970 Dourados, MS, Brasil \\ ${ }^{2}$ Universidade Federal de Lavras/UFLA, Departamento de Ciências Florestais, \\ Campus Universitário, Caixa Postal 3037, 37200-000 Lavras, MG, Brasil \\ ${ }^{3}$ Universidade Federal de Viçosa/UFV, Av. Peter Henry Rolfs, s/n, \\ Campus Universitário, 36570-000 Viçosa, MG, Brasil
}

Manuscript received on May 8, 2013; accepted for publication on October 14, 2013

\begin{abstract}
This work aimed to characterize the re-induction of desiccation tolerance (DT) in germinated seeds, using polyethylene glycol (PEG 8000). Cell changes were investigated through cytological assays (cell viability and transmission electronic microscopy) as well as DNA integrity during loss and re-establishment of DT. The loss of DT was characterized by drying germinated seeds with different radicle lengths $(1,2,3,4$ and $5 \mathrm{~mm}$ ) in silica gel, decreasing the moisture content to ten percentage points intervals, followed by prehumidification $(100 \% \mathrm{RH} / 24 \mathrm{~h})$ and rehydration. To re-induce DT, germinated seeds were treated for $72 \mathrm{~h}$ with PEG (-2.04 MPa) and PEG $(-2.04 \mathrm{MPa})+\mathrm{ABA}(100 \mu \mathrm{M})$ before dehydration. Germinated seeds did not tolerate desiccation to $10 \%$ moisture content, irrespectively of the radicle length. However, when incubated in PEG, those with 1 and $2 \mathrm{~mm}$ long radicle attained $71 \%$ and $29 \%$ survival, respectively. The PEG+ABA treatment was efficient to re-establish DT in seeds with $1 \mathrm{~mm}$ long radicles (100\% survival). The ultrastructural assays of the cells of germinated seeds with 2 and $5 \mathrm{~mm}$ length confirmed the obtained physiological results. Germinated seeds of $C$. fissilis constitute a useful tool for desiccation tolerance investigations.
\end{abstract}

Key words: cytological alterations, DNA integrity, seedlings, moisture content.

\section{INTRODUCTION}

There is an increasing concern worldwide on the uncontrolled exploitation and depletion of the earth's natural resources, especially affecting the plant diversity in tropical forests. The extinction potential of a species is related to the degree of its biological vulnerability and the degree of threat by biotic and abiotic factors. Therefore, the need for conservation is exceptionally high

Correspondence to: Tathiana Elisa Masetto

E-mail:tmasetto@gmail.com and of great importance to preserve this plant heritage for posterity. One of the most effective biological techniques to conserve this biodiversity is the establishment of gene banks, such as $e x$ situ conservation (Phartyal et al. 2002). The call to explore ex situ strategies for key groups of species is long-standing, but in practice only one, seed banking, is used for the maintenance of most collections ex situ, often at internationally agreed standards. Seeds are relatively easy to collect, can represent a range of genetic diversity in the species 
if harvested from a population of individuals and can be stored in a relatively small space ( $\mathrm{Li}$ and Pritchard 2009).

Given the appropriate facilities, storage for all these purposes can readily be achieved - but only if the seeds exhibit orthodox post-harvest physiology (Roberts 1973). Developing orthodox seeds acquire the ability to tolerate desiccation relatively early, during the phase of reserve accumulation, preceding the final developmental phase on the parent plant, i.e. maturation drying, upon which there is a switch from a developmental to a germinative mode. The ability of orthodox seeds to withstand severe desiccation is also dependent on the drying rate, which has been shown to affect seed survival after drying (Pammenter and Berjak 1999).

Recalcitrant seeds, in contrast, are characterized by short post-harvest life spans, from some days to a few months, or, for temperate species, a year or two, as long as such seeds are able to tolerate low (not sub-zero) temperatures. Besides producing shortlived seeds, many of the recalcitrant-seeded species are threatened by overexploitation, indiscriminate harvesting and habitat loss (Berjak 2005).

It has been suggested that germinated orthodox seeds can be used as a model system for studies on recalcitrance, based on the fact that upon germination, orthodox seeds lose desiccation tolerance (DT) progressively, becoming comparable to the recalcitrant types. Many processes, at a physiological, cellular and molecular level, involved with the loss of DT in germinated orthodox seeds, may be similar to those responsible for the desiccation sensitivity (DS) shown by recalcitrant seeds. Another advantage of working with germinated orthodox seeds is the feasibility of the re-establishment of its DT through the use of relatively simple techniques, such as osmotic stress and exogenous ABA. Such a system has thus the great advantage of allowing comparisons among different degrees of DT and DS within the same species, and appears as an outstanding tool for studies on the mechanisms responsible for these traits in seeds (Leprince et al. 2000, Buitink et al. 2003, Faria et al. 2005, Vieira et al. 2010).

Among the techniques used to detect the changes that occur in the cells upon stress is the DNA electrophoresis (Faria et al. 2005, Sliwinska 2009). The DNA cleavage into internucleosomal fragments and the DNA degradation in gel are accepted as a marker for programmed and passive cellular death in animal and plant cells, respectively (McCabe and Leaver 2000). Another important technique to evaluate cell alterations is the electronic transmission microscopy, which allows for the analysis of structures changes that occur when sensitive tissues are subjected to water stress.

In order to propose a new system to study cellular aspects and DNA integrity in postgermination DT, seeds of Cedrela fissilis, a native tree from the Brazilian Atlantic Forest, were used. Cedrela fissilis Vell - Meliaceae grows mainly in the Semideciduous and Atlantic Forests in Brazil. Its wood is largely used by the furniture market, civil, naval and aeronautic construction. C. fissilis tree is also recommended for landscaping. The cell changes during loss and re-establishment of DT in C. fissilis germinated seeds were investigated.

\section{MATERIALS AND METHODS}

\section{SEed Collection AND PROCESSING}

Ripe fruits were collected at the beginning of their dehiscence from about 20 seed trees in Lavras, south of the state of Minas Gerais ( $\left.21^{\circ} 14^{\prime} \mathrm{S}, 45^{\circ} 00^{\prime} \mathrm{W}\right)$. Seed processing (extraction of the seeds from the opened fruits and removal of their wings) was done at the Tree Seed Laboratory (Forest Science Department, Federal University of Lavras -UFLA), in Lavras, MG, Brazil.

\section{Moisture Content Determination}

Seed moisture content was assessed in four replications of $2 \mathrm{~g}$ each, by oven-drying at $103 \pm 2{ }^{\circ} \mathrm{C}$ for 17 hours and expressed as percentage on a fresh weight basis. 


\section{GERMINATION TEST}

Initially, seeds were disinfested with $2 \%$ sodium hypochlorite for two minutes, and then put to germinate on moist filter paper in germination boxes. The experiment was carried out in the incubation chamber as B.O.D. (Biochemical Oxygen Demand), under $25^{\circ} \mathrm{C}$ and constant white light.

\section{IMBIBITION CURVE}

Seeds put to germinate as described above were weighed daily during seven days. Ten replications of ten seeds each were used.

\section{AsSESSMENT OF Loss OF DesicCATION TOLERANCE After} GERMINATION

After germinating the seeds as described above, those that attained 1, 2, 3, 4 and $5 \mathrm{~mm}$ radicle length were dehydrated above a layer of activated silica gel $(8 \% \mathrm{RH})$ in plastic boxes, sealed with plastic film. Silica gel was changed on a regular basis, as soon as it changed color (from dark blue to light blue). During dehydration, successive weightings were done so that the weight found was in accordance with the target moisture content, through the expression proposed by Cromarty et al. (1985). After dehydration, seeds were pre-humidified in humid chamber $(100 \% \mathrm{RH})$ for 24 hours, at $25^{\circ} \mathrm{C}$, and then rehydrated (on moist paper at $25^{\circ} \mathrm{C}$ and constant white light). After rehydration, germinated seeds that survived and developed into normal seedlings were considered desiccation tolerant. Four replications with 25 germinated seeds for each radicle length were carried out.

\section{RE-INDUCTION OF DESICCATION TOLERANCE THROUGH}

INCUBATION IN PEG AND PEG + ABA

The germinated seeds with 1, 2, 3, 4 and $5 \mathrm{~mm}$ radicle length were imbibed on filter paper, in $20 \mathrm{~mL}$ of PEG 8000 solution (380 grams dissolved in 1 liter of water, according to Michel and Kaufmann (1973) or $\mathrm{PEG}+\mathrm{ABA}(100 \mu \mathrm{M})$ at $5^{\circ} \mathrm{C}$ for 72 hours in a Petri dish. At such temperature the osmotic potential of the solution was $-2.04 \mathrm{MPa}$, which did not allow that radicles continued to grow. After this period, seeds were taken from the solution, washed in running water to remove the PEG residues, and dried at room temperature on paper towel, so that the excess of water was eliminated. Following, the seeds moisture content was assessed. Afterwards, seeds were dehydrated in activated silica gel $(8 \%)$ at $20^{\circ} \mathrm{C}$ until every ten $( \pm 2)$ percentage points of decrease, down to the original seeds moisture content. They were then pre-humidified in humid air (100\% RH) for $24 \mathrm{~h}$ at $25^{\circ} \mathrm{C}$ and rehydrated as described previously. Seedlings that resumed normal growth after rehydration were considered desiccation-tolerant. Four replications with 25 germinated seeds for each radicle length were carried out.

DNA EXTRACTION AND ELECTROPHORESIS TO ASSESS DNA INTEGRITY

In order to assess the effect of dehydration on DNA integrity, chromosomal DNA was extracted from 1,2 and $5 \mathrm{~mm}$ radicle tip. DNA extraction was performed by using the cetyltrimethylammonium bromide solution - CTAB (Murray and Thompson 1980), as follows: samples were ground into powder in liquid nitrogen and transferred to a 2 $\mathrm{mL}$ microtube. Then, $800 \mu \mathrm{L}$ CTAB solution $2 \%$ and $2 \% \beta$-mercaptoethanol pre-warmed at $65^{\circ} \mathrm{C}$ was added, keeping the tube at this temperature for 40 minutes. Next, $800 \mu \mathrm{L}$ chlorophorm-isoamyl alcohol (24:1) was added and the microtubes were inverted for 5 minutes and centrifuged at $7900 \mathrm{rpm}$ for 10 minutes at room temperature. Supernatant was transferred to a new microtube and $2 \mu \mathrm{L}$ RNAase $(10 \mathrm{mg} / \mathrm{mL})$ was added, being kept at $37^{\circ} \mathrm{C}$ for one hour. After, 1 volume of cold isopropanol was added and the tubes were kept at $-20^{\circ} \mathrm{C}$ for 12 hours. Tubes were then centrifuged at $14000 \mathrm{rpm}$ at $4^{\circ} \mathrm{C}$ for 10 minutes and supernatant was discharged. $800 \mu \mathrm{L}$ of ethanol $70 \%$ was added and after 10 minutes, tubes were again centrifuged at $7900 \mathrm{rpm}$ at $4^{\circ} \mathrm{C}$ for 10 minutes in order to 
remove residues of CTAB. Tubes were then inverted on a filter paper to dry the pellet, which was then dissolved in $10 \mu \mathrm{L}$ TE $\mathrm{pH} 8.0$ (10mM TRIS- $\mathrm{HCl}$ and $1 \mathrm{mM}$ EDTA). The amount of $4 \mu \mathrm{L}$ DNA per sample was electrophoresed on an agarose gel (1\%) in TAE buffer (40 mM Tris-acetate/1 mM EDTA, pH 8) and visualized by staining with ethidium bromide.

Cytological AsSESSMENT OF RADicLes AFter RE-INDUCTION TO DESICCATION TOLERANCE

According to the results obtained in the previous experiments, 1, 2 and $5 \mathrm{~mm}$ long radicles, fresh and incubated in PEG 8000, dehydrated in silica gel and rehydrated, were chosen for cytological evaluation, in accordance to Guerra and Souza (2002) recommendations. The radicle tips were collected, fixed in Carnoy's solution $\{$ methanol:acetic acid $-(3: 1)\}$ and stored at $-20^{\circ} \mathrm{C}$ until the slide preparation. Initially, the radicle tips were taken from the fixative solution and submitted to two washes in distilled water (5 minutes each). Subsequently, radicle tips were dried on filter paper and macerated in an enzymatic solution $\{2 \%$ cellulase (Sigma): 20\% pectinase solution (Sigma) diluted in phosphate-citrate tampon $\mathrm{pH} 4.8\}$ at $37^{\circ} \mathrm{C}$ for 6 hours. After that, slides were prepared through the cellular dissociation technique, as described by Carvalho and Saraiva (1993), and stained with Giemsa $5 \%$ for 12 minutes. The slides were evaluated on light microscope (Leica) and images were captured by a Nikon digital micro camera connected to the microscope and transferred to a computer. Cellular morphology of radicle meristem before and after drying was compared. Five slides for each treatment were analyzed, evaluating 200 cells per slide.

\section{Cellular Morphology ANAlysis Through EleCtronid}

MicROSCOPY TRANSMISSION

The 1, 2 and $5 \mathrm{~mm}$ long radicle ( 5 per treatment) fresh and incubated in PEG 8000, dehydrated in silica gel and rehydrated, were fixed in the modified Karnovsky's solution (glutaraldehyde $2,5 \%$; formaldehyde $2 \%$ in a cacodylate solid buffer 0.05M; $\mathrm{CaCl}_{2}$ 0.001M, pH 7.2). Samples were washed three times (10 minutes each) with the cacodylate buffer $0.05 \mathrm{M}$ and were then fixed in an aqueous solution of osmium tetroxide $1 \%$ for $2 \mathrm{~h}$, at room temperature. Later, samples were contrasted in uranyl acetate $(0.5 \%)$ for 12 hours, at $4^{\circ} \mathrm{C}$, and dehydrated in an acetone gradient $(25 \%, 50 \%$, $75 \%, 90 \%$ and $100 \%$ three times). Afterwards, a resin infiltration was done, and the material was included in an increasing gradient of Spurr/acetone $30 \% / 8 \mathrm{~h} ; 70 \% / 12 \mathrm{~h}$ and $100 \%$ twice, for 24 hours each, the samples having been transferred to silicon molds and polymerized at $70^{\circ} \mathrm{C}$ in an incubator, for 48 hours. The sections were made with a ReichartJung ultramicrotome, whose diamond knife allowed for the sectioning of tissues with less than $100 \mathrm{~nm}$ width, and contrasted with uranyl acetate followed by lead citrate ( 3 minutes). Samples were evaluated on transmission electronic microscope (Zeiss EM 109, Carl Zeiss, Jena, Alemanha), at $80 \mathrm{kV}$, using radicle meristem cells. The activities mentioned in this item were conducted at the Laboratory of Electronic Microscopy (Department of Phytopatology, Federal University of Lavras).

\section{RESULTS}

GERMINATION AND LOSS OF DESICCATION TOLERANCE

DURING IMBIBITION OF C. fissilis SEEDS

To determine the stage of imbibition suitable for the re-induction of DT in radicles of $C$. fissilis seeds, germinability (Fig. 1) and desiccation tolerance (Fig. 2A) were first characterized. Upon imbibition at $25^{\circ} \mathrm{C}$, germination started after 144 hours as measured by the time of radicle protrusion and by $196 \mathrm{~h} 81 \%$ of the seeds had protruded radicles (Fig.1). Phase 1 of imbibition, characterized by a fast increase in fresh weight occurred in the first $48 \mathrm{~h}$. Between $48 \mathrm{~h}$ and $120 \mathrm{~h}$ of imbibition, the increase in fresh weight was very small, characterizing the 
plateau or phase 2 of imbibition (Bewley and Black 1994). Visible germination (radicle protrusion) started after $144 \mathrm{~h}$ of imbibition, with germinated seeds (seedlings) entering phase 3 and resuming the increase in fresh weight (Fig. 1).

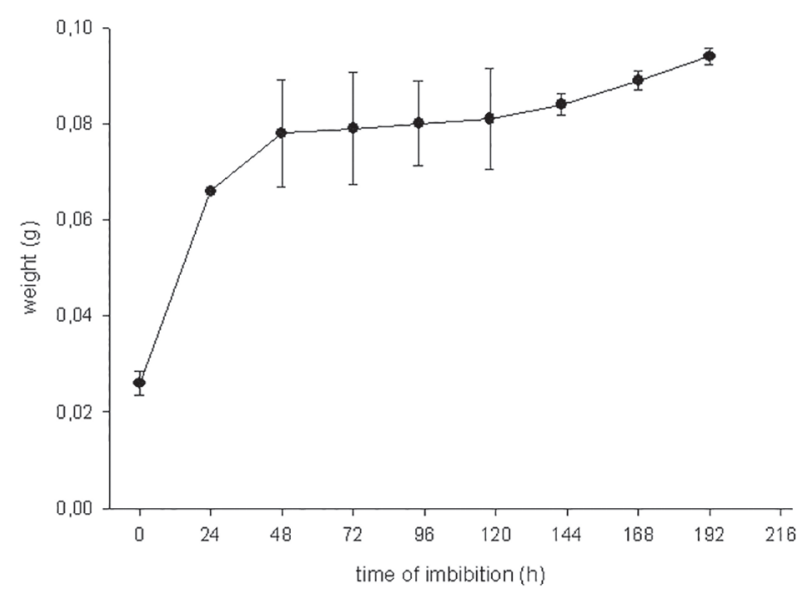

Fig. 1 - Inbibition curve of Cedrela fissilis seeds.

DT was related to the moisture content (MC) of the protruded radicle after dehydration (Fig. 2A). Upon rehydration, seeds that germinated or showed resumption of growth were considered desiccation tolerant. Germinated seeds could be dried to a radicle MC of $50 \%$ without affecting the resumption of growth upon rehydration. Below $40 \%$ MC the percentage of survival declined considerably, and complete loss of viability was observed at about $10 \% \mathrm{MC}$.

\section{RE-INDUCtion of DESICCATION TOLERANCE In SENSITIVE}

\section{RADICLES BY OSMOTIC STRESS}

Germinated seeds of $C$. fissilis with different radicle lengths were placed in an osmotic solution of -2.04 $\mathrm{MPa}$ at $5^{\circ} \mathrm{C}$ for 3 days after which seeds were rinsed, dehydrated and rehydrated. In seeds with protruded radicles of 1 and $2 \mathrm{~mm}$, DT was re-established in $71 \%$ and $29 \%$ of the seeds, respectively, at $10 \% \mathrm{MC}$.

Even at moisture content as high as $20 \%$, it was not possible to re-establish DT without the osmotic stress. Seeds with protruded radicles of $3 \mathrm{~mm}$ and longer could not be rendered desiccation tolerant (Fig. 2B).
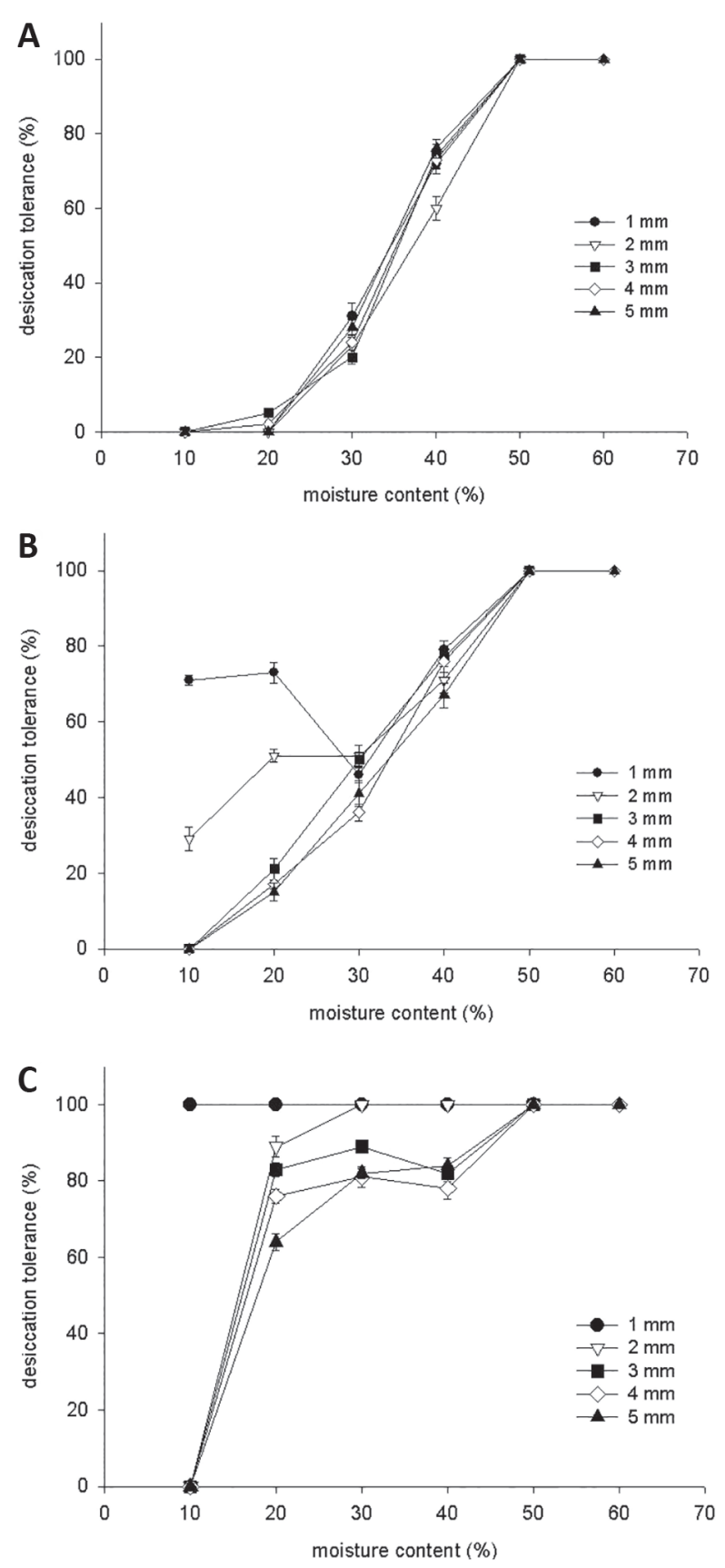

Fig. 2 - Desiccation tolerance in germinated C. fissilis seeds dehydrated in silica gel to different moisture contents (A). Desiccation tolerance of germinated C. fissilis seeds PEG-treated and dehydrated to different moisture content (B). Desiccation tolerance of germinated $C$. fissilis seeds $\mathrm{PEG}+\mathrm{ABA}$-treated and dehydrated to different moisture content (C).

Manipulation of PEG incubation and water potential did not lead to an induction of DT in 3 $\mathrm{mm}$ long radicles. The osmotic treatment of the 
germinated seeds with $1 \mathrm{~mm}$ protruded radicles increased the percentage of DT from $0 \%$ to $71 \%$ (Fig. 2B). PEG-treated germinated seeds with a radicle length of $2 \mathrm{~mm}$ survived dehydration to $20 \% \mathrm{MC}(51 \% \mathrm{DT})$, but failed to resume elongation or undergo cell division and eventually died after dehydration to $10 \% \mathrm{MC}$.

RE-INDUCTION OF DESICCATION TOLERANCE IN GERMINATED SEEDS By INCUBATION IN PEG+ABA

In developing seeds, ABA content generally peaks half-way through development and declines upon maturation drying as a result of differences in ABA levels during seed development (Groot and Karssen 1992). To investigate the conditions governing the re-establishment of DT, the effect of radicle length on the dynamics of the re-induction was studied. Fig. 2C shows the percentage of DT obtained at different water content, using PEG+ABA treatment. At low water content, desiccation tolerance could still be re-established (Fig. 2C). For each radicle length, the reinduction of DT with PEG+ABA treatment led to a higher percentage of radicle survival following desiccation and rehydration.

The treatment-response curve indicated that 1 $\mathrm{mm}$ long radicle maintained the ability to tolerate desiccation and resume growth in all moisture content. At 20\% MC, in germinated seeds with protruded radicles of 2, 3, 4 and $5 \mathrm{~mm}$, DT was re-established in $89 \%, 83 \%, 76 \%$ and $64 \%$ of the seeds, respectively. However, at $10 \% \mathrm{MC}$ germinated seeds with $2 \mathrm{~mm}$ or longer did not survive dehydration. Decreasing water content from $20 \%$ to $10 \%$ prevented the re-induction of DT, with the exception of germinated seeds with protruded radicles of $1 \mathrm{~mm}$. Since ABA was not able to re-establish DT in germinated seeds with radicle length of $2 \mathrm{~mm}$ or longer, only the PEGtreated germinated seeds with 1,2 and $5 \mathrm{~mm}$ radicle length were used to study the changes in moisture content and the cytological alterations.
Detection of DNA DEgRAdATION IN GERMINATED SEEDS SUBJECTED TO DEHYDRATION

Analysis of DNA integrity in protruded radicles revealed DNA degradation in 2 and $5 \mathrm{~mm}$ long PEG-treated radicle cells excised from germinated seeds subjected to dehydration (Fig. 3; lanes 2 and 5), while desiccation tolerant $1 \mathrm{~mm}$ protruded radicle showed intact DNA. DNA degradation was much stronger in $5 \mathrm{~mm}$ long radicles than in $2 \mathrm{~mm}$ long radicles, characterizing the passive cell death or necrosis in C. fissilis germinated seeds (Fig. 3).

Living Cells Assessment in GeRminated SeEds After DEHYDRATION

This fast and accurate method for the estimation of living cells allows detection of nuclei at different morphological states in meristematic tissues such as radicle tips, and thus makes it possible to follow changes in the physiological state of a seedling. The observation of nuclei morphology allowed for the confirmation of the cell death after dehydration and rehydration, determined by the reduced size and intense coloration in cell nuclei (Fig. 4). This was particularly strong in $5 \mathrm{~mm}$ long radicles. The cell death in germinated seeds with 1,2 and $5 \mathrm{~mm}$ long radicles were $41 \%, 60 \%$ and $74 \%$, respectively, as assessed through microscope (Fig. 4).

CYTOLOGICAL FACTORS INFLUENCING THE RE-INDUCTION OF DESICCATION TOLERANCE

To obtain an insight into the structural changes before dehydration and after rehydration, images of meristematic cells were obtained from transmission electron microscopy (TEM) of $C$. fissilis germinated seeds in order to characterize their changes after dehydration and to relate them to the loss of DT (Fig. 5). Before dehydration, PEG-treated germinated seeds showed the cytoplasm located along the cell wall, with normal organization (Fig. 5A, 5C and 5E). The cell wall was also normal in appearance and a large vacuole, which completely filled the cell, was present. Amyloplasts were present in large numbers. 


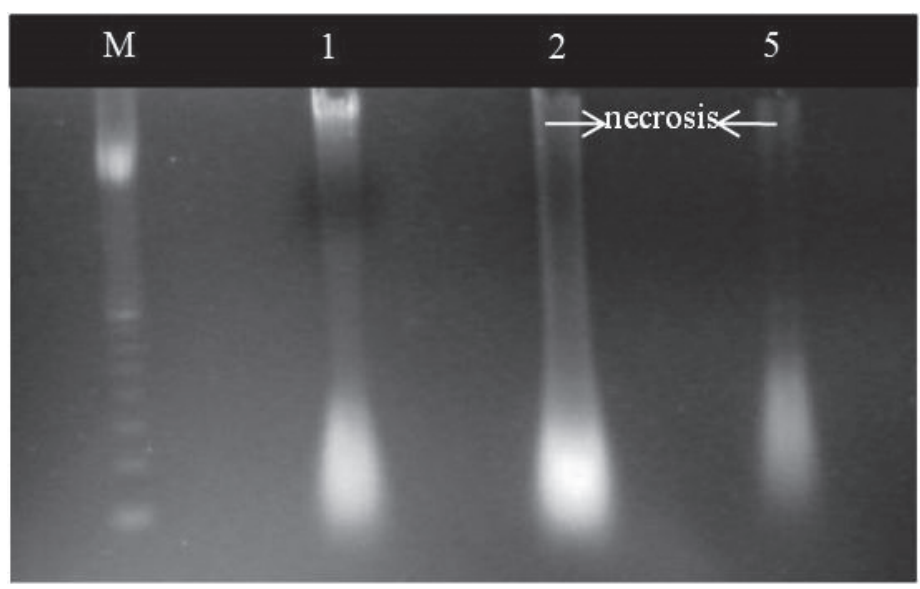

Fig. 3 - Agarose gel 1\% with genomic DNA samples $(5 \mu \mathrm{g})$ extracted from radicle tips of germinated seeds of Cedrela fissilis after PEGtreatment and dehydration. M: $1 \mathrm{~Kb}$ Plus DNA Ladder Marker, 1: $1 \mathrm{~mm}$ long radicle, 2: $2 \mathrm{~mm}$ long radicle and 5: $5 \mathrm{~mm}$ long radicle. Arrows show passive cell death (PCD).

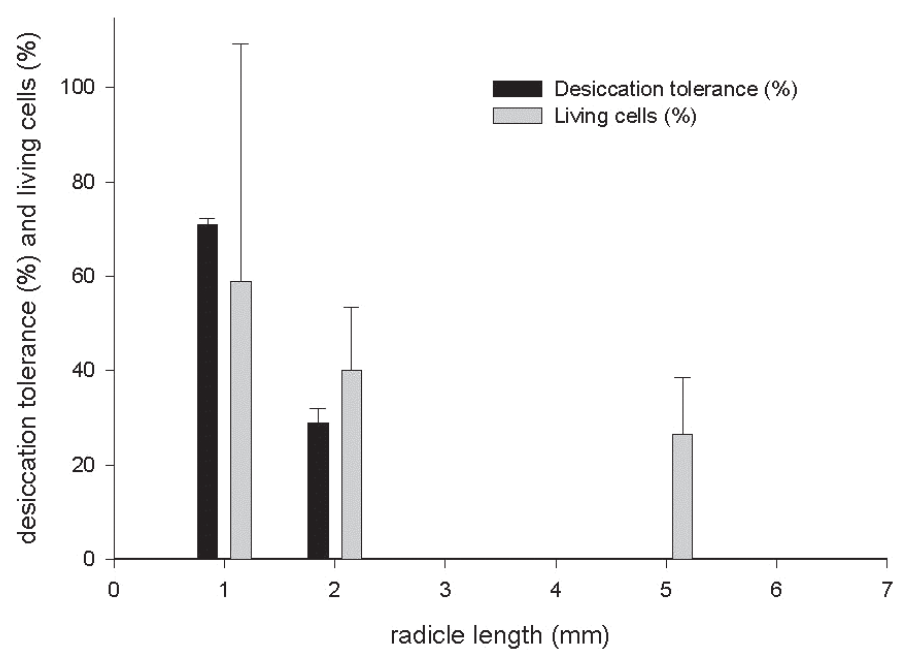

Fig. 4 - Desiccation tolerance and living cells from 1, 2 and $5 \mathrm{~mm}$ long radicles of Cedrela fissilis germinated seeds after PEG treatment, dehydration in silica and pre-humidification.

The TEM micrographs revealed that cells of PEG-treated $1 \mathrm{~mm}$ long radicles did not show many changes in this region after dehydration (Fig. 5B). However, PEG-treated seeds with 2 and $5 \mathrm{~mm}$ radicle length collapsed and/or lost cellular compartmentalization after dehydration and rehydration (Fig. 5D and Fig. 5F). Severely damaged cells appeared totally devastated with cell wall folding and fragmented cytoplasm.

\section{DISCUSSION}

Several researches have shown that it is possible to re-establish DT in germinated seeds. This study demonstrates that the re-induction of DT can be achieved in C. fissilis germinated seeds. DT expressed as percentage of normal seedlings was measured by the surviving radicle, hypocotyl and cotyledon. Damage could occur to the radicle, but the germinated seeds that eventually resumed 
growth were considered normal seedlings. This study demonstrates that the radicle length at which C. fissilis seedlings lose DT, varies with the PEG or $\mathrm{PEG}+\mathrm{ABA}$ treatment and the MC.

Besides the expected variation, at the beginning of the germinative process, C. fissilis seeds lost the capacity to tolerate dehydration completely, resembling recalcitrant seeds. After germination, the lack of ability to re-induce protection after drying at $20 \%$ MC resulted in the total number of dead radicles with all the observed lengths. The hydration of the membranes is needed to start the metabolic events, and the starch and protein hydration is necessary to activate the metabolism, producing essential energy and compounds for seedling growth (Kikuchi et al. 2006). Thus, some species show the capacity to tolerate seedling desiccation as a strategy to resist the scarcity of rains in arid regions (Zhang et al. 2005).

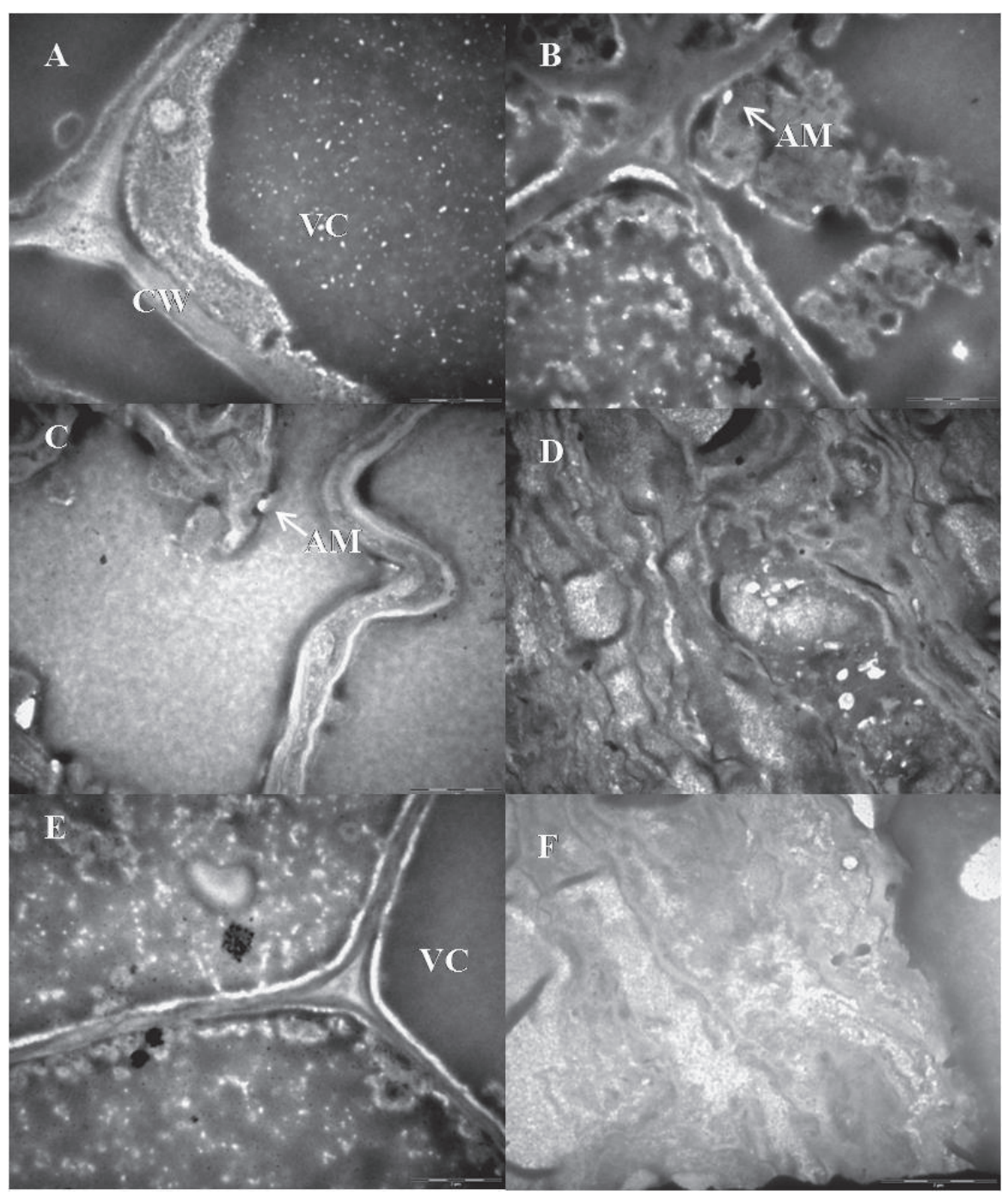

Fig. 5 - Images of meristematic cells obtained by Transmission Electron Microscopy of Cedrela fissilis germinated seeds with 1(A), 2 (C) and 5 (E) $\mathrm{mm}$ long radicle before dehydration. B, D and F correspond to cells from 1, 2 and $5 \mathrm{~mm}$ long radicles, respectively, after incubation in PEG (-2.04 MPa), dehydration in silica gel to $10 \% \mathrm{MC}$ and rehydration. $\mathrm{AM}=$ amyloplasts. $\mathrm{CW}=$ cell wall. $\mathrm{VC}=$ vacuole. Bars: $2 \mu \mathrm{m}$. 
The decrease of moisture content of $C$. fissilis germinated seeds at every 10 percentage points, gradually permitted some inferences about the dehydration behavior. The chances of re-establishment after drying and, consequently the normal development of seedling were highly dependent on the radicle length and the $\mathrm{MC}$ reached, which when at reduced levels (lower than 30\%) caused the death of the emerged radicles with 3, 4 and $5 \mathrm{~mm}$ length. The PEG treatment (-2.04 MPa) resulted in a radicle-length-dependent and was efficient to re-induce the DT in $1 \mathrm{~mm}$ long radicle germinated seeds, which showed $73 \%$ survival when the MC was reduced to $20 \%$, maintaining the high percentage of DT (71\%) when the MC reduced to $10 \%$ (Fig. $2 \mathrm{~B}$ ). PEG-treated $2 \mathrm{~mm}$ long radicle showed a small increase in survival $(29 \%)$ as the moisture content reduced to $10 \%$. Considerable variations concerning the other evaluated radicle lengths, which presented remarkable DT decrease according to the MC, were not observed.

Leprince et al. (2000) reported that germinated seeds of cucumbers and peas are able to re-establish DT through osmotic stress, by incubating the seeds in PEG. Considering that the re-induction of DT is reached through the radicles exposure to low water potential, changes in the gene expression may be related to the DT induction and to the osmotic stress condition. Buitink et al. (2004) reported that the level of transcripts which controlled enzymes stress response did not increase during the PEG incubation $(-1.7 \mathrm{MPa})$ of germinated seeds of Medicago truncatula with $5 \mathrm{~mm}$ radicle length, which remained desiccation sensitive. However, the $3 \mathrm{~mm}$ long radicle PEG incubated during 24 hours, showed an increase in the transcript levels, concomitantly with re-induction of DT. M. truncatula $2.7 \mathrm{~mm}$ radicle length initially submitted to the PEG treatment, combined with low temperature re-established the DT. After germination, the desiccation sensitive radicles re-acquired tolerance to dehydration by PEG treatment, indicating that there is a gap (between 1 and $3 \mathrm{~mm}$ radicles length) between the seedling development and its establishment (Buitink et al. 2003). To the authors, osmotic treatment is able to induce changes through different metabolic routes, simultaneously with the radicle growth paralyzation. The endogenous carbon sources which are generally designated to cellular division and expansion are deviated from the cellular wall synthesis to constitute oligosaccharides that are probably accumulated during the re-establishment of DT. During incubation of $C$. fissilis germinated seeds above $2 \mathrm{~mm}$ radicle length in PEG, which provides a slow dehydration resulting in a slightly MC reduction (Fig. 2B), it is possible that changes occurred that did not permit the re-establishment of DT and such radicles remained sensitive to dehydration even after the osmotic treatment. Likewise, the time and the temperature of PEG incubation and the water potential used may not have been efficient to re-establish DT in 3, 4 and 5 $\mathrm{mm}$ long radicle dehydrated to $10 \% \mathrm{MC}$.

The data obtained from the PEG + ABA treatment to re-establish the DT in C. fissilis radicles (Fig. 2C) shows that $1 \mathrm{~mm}$ long radicle of germinated seeds kept a high survival rate (100\%), even when the MC was gradually reduced at each 10 percentage points. Germinated seeds $2 \mathrm{~mm}$ long radicle also survived dehydration to $20 \% \mathrm{MC}$, but not to $10 \% \mathrm{MC}$. The osmotic treatment $+\mathrm{ABA}$ also provided an increase in the survival rates of 3, 4 and $5 \mathrm{~mm}$ radicles length when dried to $20 \% \mathrm{MC}$, however, when reducing to $10 \% \mathrm{MC}$, radicles did not survive. ABA may also induce the DT, as firstly shown by Bartels et al. (1998). Buitink et al. (2003) suggested that ABA and osmotic stress act as two independent stimuli, required to re-induce the DT. Alternatively, the osmotic treatment could inhibit radicle growth until ABA was accumulated and its functions performed. Sreedhar et al. (2002) related that the addition of ABA to the culture medium of $M$. truncatula somatic embryos provided 
a metabolic diminution which, consequently, increased the DT of the embryos, but slow drying without ABA treatment caused their death. In the present research, isolated osmotic treatment did not increase DT when compared to the treatment PEG + ABA. Only $1 \mathrm{~mm}$ radicle length maintained high survival during all the dehydration levels and 2, 3, 4 and $5 \mathrm{~mm}$ long radicle also presented an increment in the normal seedling formation after ABA treatment and subsequent $\mathrm{MC}$ reduction.

Possibly, ABA performed a role of adaptation to stress. ABA accumulation in vegetal tissues corresponds to metabolic and physiologic changes that occur during water stress in seedlings. The exogenous ABA application improves seedling adaptation after water stress (Boominathan et al. 2004) and, when exogenously applied, leads to gene expression which respond to dehydration (Seki et al. 2002, Wang et al. 2002, Narusaka et al. 2004).

Considering the results from the re-induction of DT in C. fissilis germinated seeds, PEG-treated 1,2 and $5 \mathrm{~mm}$ radicle lengths, submitted to silica gel dehydration and rehydrated were selected for cytological evaluations. These radicle lengths were chosen because they allowed for clear visualization of differences among the systems obtained from the PEG treatment. From the selected models, it was possible to obtain a contrasting system to investigate the changes which occurred during the loss and re-establishment of DT in C. fissilis radicles using techniques of cellular biology.

The genomic DNA electrophoresis of $C$. fissilis radicles indicated that the DNA extracted from 1 $\mathrm{mm}$ long radicles, showed a strong pattern, but with a stain along its profile (Fig. 3), probably due to the $29 \%$ radicles that did not re-establish the DT after dehydration. A possible explanation is that molecular changes were triggered early during dehydration of germinated seeds and occurred consistently in all seeds.

The band referring to the DNA extracted from the $2 \mathrm{~mm}$ long radicles was partially degradated, as indicated by the smeared band, as was the
DNA from $5 \mathrm{~mm}$ long radicles, which weakened band also presented DNA degradation signals. The occurrence of such DNA aspect is reported in literature as passive cell death or necrosis, a non controlled event. When cells die due to an abiotic factor, the DNA is not cleaved and does not move during the electrophoresis or, alternatively, under a determined stress, it is more damaged by the factor than by the endonucleases and is visualized as a smear band on the gel (McCabe and Leaver 2000, Masetto et al. 2008, Kranner et al. 2011).

The passive cell death is caused by a severe tissue injury, which, in animals, results in the development of inflammatory symptoms (Eckardt 2006), and in plants, especially seeds, causes the loss of viability (Kranner et al. 2006). The life or death choices a cell makes may be determined by a wide range of physiological considerations. Without a doubt, one such important consideration in determining whether a cell survives or mounts a programmed cell death versus necrotic response may be determined by the redox state of the cell. Kranner et al. (2011) related that non-programmed cell death as observed in $C$. fissilis germinated seeds can be related as lipid peroxidation, "random damage" to nucleic acids, including strand breaks, covalent modifications, point mutations and protein modification including disulphide cross-linking and carbonylation.

The PEG incubation can induce the synthesis of proteins that perform the protection of DNA (Faria et al. 2005). Although, according to the results, it is most probable that the DNA did not make the required repair to maintain the genetic integrity after dehydration and rehydration. In addition, in the cytological evaluation of the $C$. fissilis radicles, the nucleus aspect with intense coloration and reduced size, confirmed the incidence of mortality in C. fissilis germinated seeds with radicle 1, 2 and $5 \mathrm{~mm}$ long (Fig. 4). Osborne and Boubriak (1997) emphasized the importance of DNA repair in determining the plant genome, considering that 
the ability to re-establish the synthesis of proteins, lipids and RNA only happens if the integrity of the genetic information is also preserved, which is also the case in $C$. fissilis germinated seeds. Thus, the cell $\mathrm{MC}$ can determine the maintenance of proteins integrity, endonucleases activation and DNA conformation (Osborne 2000).

Hence, the ultra-structural changes that occurred in cells from C. fissilis radicles PEGtreated, dehydrated and rehydrated confirmed the occurrence of cell death (Fig. 5). The cytoplasmic density, the normal cell wall conformation and the cellular content organization could be seen in 1, 2 and $5 \mathrm{~mm}$ long radicles non-subjected to water stress (Fig. 5A, 5C and 5E, respectively). Besides, after dehydration and rehydration of the $1 \mathrm{~mm}$ long radicles (Fig. 5B), cells maintained the cellular wall integrity, but with initial alterations in the cellular content. Moreover, it is important to evaluate how many cells are damaged to affect the viability. Ingram and Bartels (1996) and Leprince et al. (1999) related that a small change in the membrane permeability does not necessarily result in the loss of viability. The death of tissue occurs when a critical portion of cells have lost their membrane integrity. The ultrastructural analysis of cells from 2 and $5 \mathrm{~mm}$ long radicles (Fig. 5D and 5F, respectively) detected alterations related to cell death, such as the loss of compartmentalization of cellular components and the cell wall and cytoplasm fragmentation. These observations are in consonance with the data found in literature (Filonova et al. 2000). Although $29 \%$ of $2 \mathrm{~mm}$ long radicles re-established growth, the verified alterations prevented the total reestablishment of DT and contributed to the total mortality of $5 \mathrm{~mm}$ long radicles in dehydrated state. To tolerate the desiccation, cells need to be protected against the lethal changes that can occur after dehydration. Among the mechanisms that can avoid such damages, there is the participation of certain soluble carbohydrates, such as raffinose and stachyose, which are involved in the formation of the glassy state and/or protection interaction with the membrane phospholipids and LEA proteins (late embryogenesis abundant). LEA proteins are involved in the stabilization of macromolecule structures in dehydrated state; hence, they allow for the membrane functional integrity after dehydration and rehydration (Buitink et al. 2002).

In addition, membrane stabilization in dehydrated state is important to DT. Sugars perform a crucial role, interacting with the hydrophilic stage of phospholipids and substituting (at least a very significant portion) the water usually occupied in this position (Hoekstra et al. 2005). The general conclusion from the dehydration and hydration experiment using PEG treatment in different radicles length of $C$. fissilis is that cytological aspects such as nucleus conformation, DNA integrity and stabilization of cellular content are necessary to the maintenance of post-germination DT. However, the radicle length up to $1 \mathrm{~mm}$ and the osmotic stress simulated with PEG or PEG +ABA were efficient in re-establishing the ability to resume the normal growth in seedlings of $C$. fissilis after dehydration.

\section{ACKNOWLEDGMENTS}

The authors acknowledge the Fundação de Amparo à Pesquisa do Estado de São Paulo (FAPESP) for the partial funding of this research, through the Project No 2005/04139-7, Conselho Nacional de Desenvolvimento Científico e Tecnológico (CNPq) and Coordenação de Aperfeiçoamento de Pessoal de Nível Superior (CAPES) for financial support.

\section{RESUMO}

O objetivo deste trabalho foi caracterizar a re-indução da tolerância à dessecação em sementes germinadas de Cedrela fissilis, utilizando polietileno glicol (PEG 8000). As mudanças celulares foram investigadas pelas avaliações citológicas (viabilidade celular e microscopia eletrônica de transmissão), bem como a integridade do DNA durante a perda e o restabelecimento da tolerância à dessecação. A perda da TD foi caracterizada pela secagem 
de sementes germinadas com diferentes comprimentos de radículas $(1,2,3,4$ e $5 \mathrm{~mm})$ em sílica gel, diminuindo o teor de água em intervalos a cada 10 pontos percentuais, seguido de pré-umidificação (100\% UR / 24h) e reidratação. Para reinduzir a TD, sementes germinadas foram tratadas durante $72 \mathrm{~h}$ com PEG (-2.04 MPa) e PEG $(-2.04 \mathrm{MPa})+$ ABA $(100 \mu \mathrm{M})$ antes da desidratação. As sementes germinadas não toleraram a secagem até $10 \%$ de teor de água, independente do comprimento de radícula. Entretanto, quando incubadas em PEG, sementes com 1 e $2 \mathrm{~mm}$ de comprimento de radícula atingiram $71 \%$ e $29 \%$ de sobrevivência, respectivamente. O tratamento com $\mathrm{PEG}+\mathrm{ABA}$ foi eficiente para restabelecer a tolerância à dessecação em sementes com radícula de $1 \mathrm{~mm}$ de comprimento (100\% de sobrevivência). As avaliações ultraestruturais das células oriundas de radículas com 2 e $5 \mathrm{~mm}$ de comprimento confirmaram os resultados fisiológicos obtidos. Sementes germinadas de C. fissilis constituem ferramenta útil para as investigações de tolerância à dessecação.

Palavras-chave: alterações citológicas, integridade do DNA, plântulas, teor de água.

\section{REFERENCES}

BARTEls D, Singh M AND SAlamini F. 1998. Onset of desiccation tolerance during development of the barley embryo. Planta 175: 485-492.

BERJAK P. 2005. Protector of the seeds: seminal reflections from southern Africa. Science 307: 47-49.

BEWLEY JDANDBLACKM. 1994. Seeds: physiology of development and germination. $2^{\text {nd }}$ ed., New York, Plenum Press, NY, USA.

Boominathan P, Shukla R, Kumar A, Manna D, Negi D, Verma PK AND ChatTOPADHYAY D. 2004. Long Term Transcript Accumulation during the Development of Dehydration Adaptation in Cicer arietinum. Plant Physiol 135: 1608-1620.

BUITINK J, HOEKSTRA FA AND LEPRINCE O. 2002. Biochemistry and Biophysics of desiccation tolerance systems. In: BLACK $M$ and PRITCHARD HW (Eds), Desiccation and Survival in Plants. CABI, Wallingford, UK, p. 293-318.

Buitink J, Thomas M, Gissot L AND LePrince O. 2004. Starvation, osmotic stress and desiccation tolerance lead to expression of different genes of the regulatory $b$ and $g$ subunits of the SnRK1 complex in germinating seeds of Medicago truncatula. Plant Cell Environ 27: 55-67.

BUITINK J, Vu BL, SATOUR P AND LEPRINCE O. 2003. The reestablishment of desiccation tolerance in germinated radicles of Medicago truncatula Gaertn. seeds. Seed Sci Res 13: 273-286.
CARVALHO CR AND SARAIVA LS. 1993. An air drying technique for maize chromosomes without enzymatic maceration. Bioth \& Histoch 68: 142-145.

Cromarty AS, Ellis RH AND RoBerTs EH. 1985. Desing of seed storage facilities for genetic conservation. Rome: IPGRI, IT.

ECKARDT NA. 2006. Programmed cell death in plants: A role for mitochondrial-associated hexokinases. The Plant Cell 18: 2097-2099.

FARIA JMR, BUITINK J, LAMMEREN AAM AND HILHORST HWM. 2005. Changes in DNA and microtubules during loss and re-establishment of desiccation tolerance in germinating Medicago truncatula seeds. J Exp Bot 56: 2119-2130.

FILONOVA LH, BozhKov PV, BRUKhIN VB, DANIEL G, ZHIVOTOVSKY B AND ARNOLD S. 2000. Two waves of programmed cell death occur during formation and development of somatic embryos in the gymnosperm, Norway spruce. J Cell Sci 113: 4399-4411.

Groot SPC AND KARSSEN CM. 1992. Dormancy and germination of abscisic acid-deficient tomato seeds. Plant Physiol 99: 952-958.

GUERRA M AND SOUZA MJ. 2002. How to observe chromossomes - A guide of techniques of vegetal, animal and human cytogenetic. Ribeirão Preto, FUNPEC, SP, BR.

HoEKSTRA FA. 2005. Differential congevities in desiccated anhydrobiotic plant systems. Integr Comp Biol 45: 725-733.

INGRAM J AND BARTELS D. 1996. The molecular basis of dehydration tolerance in plants. Annu Rev Plant Physiol Plant Mo1 Biol 47: 377-403.

KikUCHI K, KoIzUmi M, IshidA N AND KanO H. 2006. Water uptake by dry beans observed by micro-magnetic resonance imaging. Ann Bot 3: 545-553.

KranNer BS, ANDERSON KM AND PRITCHARD HW. 2006. Glutathione half-cell reduction potential: A universal stress marker and modulator of programmed cell death? Free Radical Bio Med 40: 2155-2165.

Kranner BS, Hongying C, Pritchard HW, Pearce SR and BIRTIC S. 2011. Inter-nucleosomal DNA fragmentation and loss of RNA integrity during seed ageing. Plant Growth Regul 63: 63-72.

LePrince O, BuitinK J AND HoeKstra FA. 1999. Axes and cotyledons of recalcitrants seeds of Castanea sativa Mill. exhibit constrating responses of respiration to drying in relation to desiccation sensitivity. J Exp Bot 50: 1515-1524.

LEPRINCE O, HARRENFJM,BUITINK J,ALBERDAMAND HOEKSTRA FA. 2000. Metabolic dysfunction and unabated respiration precede the loss of membrane integrity during dehydration of germinating radicles. Plant Physiol 122: 597-608.

LI DZ AND PRITCHARD HW. 2009. The science and economics of ex situ plant conservation. Trends in Plant Sci 14: 614-621.

MasetTo TE, FARIA JMR, DAVIDE AC AND SILVA EAA. 2008 Desiccation tolerance and DNA integrity in Eugenia pleurantha O. Berg. (Myrtaceae) seeds. Rev Bras Sementes 30: 51-56.

McCABE PF AND LeAVer CJ. 2000. Programmed cell death in cell cultures. Plant Mol Bio 44: 359-368. 
Michel BE AND KAUfMANN MR. 1973. The osmotic potential of polyethylene glycol 6000. Plant Physiol 51: 914-916.

MURRAY MG AND THOMPSON WF. 1980. Rapid isolation of high molecular weight plant DNA. Nucleic Acids Res 8: 1134-1137.

NARUSAKA Y, NARUSAKa M, SEKI M, UMEZAWA T, IShIDA J, NAKAJIMA M, ENJU A AND SHINOZAKI K. 2004. Crosstalk in the responses to abiotic and biotic stresses in Arabidopsis: Analysis of gene expression in cytochrome P450 gene superfamily by cDNA microarray. Plant Mol Bio 55: 327-342.

OSBORNE DJ. 2000. Hazards of a germinating seed: available water and the maintenance of genomic integrity. Isr J Plant Sci 48: 173-179.

OSBORNE DJ AND BOUBRIAK II. 1997. DNA status, replication and repair in desiccation tolerance and germination. Basic and applied aspects of seed biology. Boston, Kluwer Academic Publishers, USA.

PAMMENTER NW AND BERJAK P. 1999. A review of recalcitrant seed physiology in relation to desiccation-tolerance mechanisms. Seed Sci Res 9: 13-37.

Phartyal SS, Thapliyal RC, KoEDAm N AND Godefroid S. 2002. Ex situ conservation of rare and valuable forest tree species through seed-gene banks. Curr Sci 83: 1351-1357.

RoBERTS EH. 1973. Predicting the storage life of seeds. Seed Sci and Technol 1: 449-514.
SEKI M, ISHIDA J, NARUSAKA M, FUJITA M, NANJO T, UMEZAWA T AND SHINOZAKI K. 2002. Monitoring expression pattern of about 7000 Arabidopsis genes under ABA treatment using full length cDNA microarray. Plant J 31: 279-292.

SLIWINSKA E. 2009. Nuclear DNA replication and seed quality. Seed Sci Res 19: 15-25.

SReEdHAR L, WOLKers WF, HoEKSTRA FA AND BEWLEy JD. 2002. In vivo characterization of the effects of abcisic acid and drying protocols associated with the acquisition of desiccation tolerance in alfafa (Medicago sativa L.) somatic embryos. Ann Bot 89: 391-400.

Vieira CV, Silva EAA, Alvarenga AA, CASTro EM AND TOOROP PE. 2010. Stress-associated factors increase after desiccation of germinated seeds of Tabebuia impetiginosa Mart. Plant Growth Regul 62: 257-263.

WANG XJ,LOH CS AND YEOH WS. 2002. Drying rate and dehydrin synthesis associated with abcisic-acid induced dehydration tolerance in Spathoglottis. J Exp Bot 53: 551-558.

Zhang F, Chen FG, HuANG EQ, ORION EO, KRUGMAN ET, FAhima T, Korol AB, NeVo E AND GutTerman Y. 2005. Genetic basis of barley caryopsis dormancy and seedling desiccation tolerance at the germination stage. Theor Applied Genet 110: 445-453. 
